(c) American Dairy Science Association, 2004.

\title{
Effect of Clinical Contagious Agalactia on the Bulk Tank Milk Somatic Cell Count in Murciano-Granadina Goat Herds
}

\author{
J. C. Corrales, ${ }^{1}$ A. Sánchez, ${ }^{1}$ C. Luengo, ${ }^{1}$ J. B. Poveda, ${ }^{2}$ and A. Contreras ${ }^{1}$ \\ ${ }^{1}$ Epidemiología y Enfermedades Infecciosas, Facultad de Veterinaria, \\ Universidad de Murcia, 30071 Murcia, Spain \\ ${ }^{2}$ Epidemiología y Medicina Preventiva, Facultad de Veterinaria, \\ Universidad de Las Palmas de Gran Canaria, 35416 Arucas, Gran Canaria, Spain
}

\begin{abstract}
From 19 herds of Murciano-Granadina goats, weekly bulk tank somatic cell count (BTSCC) were performed from October to April, and suspicious milk ( $\mathrm{n}=182)$, synovial fluid, and ocular swabs $(\mathrm{n}=15)$ from diseased goats were processed for mycoplasma isolation and identification. Also BTSCC from 65 herds were determined ( $\mathrm{n}=2693$ ). A mixed model procedure was used to establish the effect of the herd and the lactation month on the BTSCC. Monthly rolling values were calculated for each herd using data collected over the preceding 3 complete months, and 4 different BTSCC thresholds were considered: $1,750,000,1,500,000$, $1,000,000$, and 750,000 cells $/ \mathrm{mL}$. The mean log BTSCC for the 7-mo study period was $5.89 \pm 0.28$ for herds without mycoplasma detection from clinical cases, 5.91 \pm 0.31 for mycoplasma-infected herds without clinical contagious agalactia (CA), and $6.47 \pm 0.32$ for the herd with clinical CA. The posthoc tests revealed that only the herd that suffered a clinical CA outbreak showed counts that were significantly higher. No significant differences were found for BTSCC between herds not showing clinical episodes of CA, regardless of whether the mycoplasma had been isolated or not. The 1,750,000-cells/mL threshold would only be surpassed by a few herds with serious mastitis problems (clinical outbreak of CA for example). Seventy percent of the goat herds studied were in compliance with the proposed European Union legal limit of 1,500,000 cells $/ \mathrm{mL}$ for goat milk.
\end{abstract}

(Key words: goat, mastitis, mycoplasma, bulk tank somatic cell count)

Abbreviation key: BTSCC = bulk tank somatic cell count, $\mathbf{C A}=$ contagious agalactia, $\mathbf{E U}=$ European Union, NMC = National Mastitis Council.

Received February 18, 2004.

Accepted June 15, 2004.

Corresponding author: A. Contreras de Vera; e-mail: acontrer @um.es.

\section{INTRODUCTION}

Milk producers currently have to comply with the high quality standards demanded by consumers, industry, and public health organizations. Present European Union (EU) legislation on this issue refers to dairy cattle (Directive 92/46ECC Council, 1992), and the industry has established a differential payment scheme according to quality, especially based on health criteria (somatic cell count; SCC) and hygiene (bacterial counts). North American legislation for dairy cattle includes a 750,000 -cells $/ \mathrm{mL}$ limit for the SCC, and the possible effects of variation from this legal limit have been studied (Adkinson et al., 2001). For goat's milk, the EU has already established the requirement of a bacterial count $<1,000,000 \mathrm{cfu} / \mathrm{mL}$, and although there is currently no set limit for the SCC, the published conclusions of the International Symposium on Somatic Cells and Milk of Small Ruminants held in Italy, propose a threshold of 1,500,000 cells/mL (Barbosa et al., 1994). This limit is far above the legal US limit of $1,000,000$ cells $/ \mathrm{mL}$ for goat's milk (Haenlein, 2002). Further, in France, there is interest in adopting a payment-by-quality scheme, including sanctions for SCC and bacterial counts $>1,000,000$ cells $/ \mathrm{mL}$ and 50,000 $\mathrm{cfu} / \mathrm{mL}$, respectively (Charpentier, 2000). However, currently, the thresholds for milk payment are 1,500,000 and $3,000,000$ cells $/ \mathrm{mL}$ at a national level for goats. Nevertheless, although IMI leads to a significant increase in the SCC of goat's milk, the relationship between the bulk tank SCC (BTSCC) and the IMI prevalence according to specific microbial agents has not yet been described.

Contagious agalactia (CA), a disease caused by mycoplasmas, is usually characterized by the 3 main symptoms: mastitis, arthritis, and keratoconjunctivitis. In general, animals suffering from mycoplasma mastitis show a large increase in their milk SCC (Poutrel et al., 1996). Although it may be assumed that the endemic presence of CA in the Mediterranean basin (Bergonier et al., 1997) will be one of the key arguments against adopting these SCC limits by goat farmers, there are few data related to the effects of mycoplasma IMI on 
the BTSCC. In the present study, we report BTSCC for several Murciano-Granadina goat herds screened for IMI caused by mycoplasma. We also discuss the potential repercussions of adopting legal limits or paymentby-quality scheme for the BTSCC on the marketing of goat milk.

\section{MATERIALS AND METHODS}

Our first objective was to determine the effect of intramammary mycoplasma infection and clinical CA on the BTSCC.

\section{Herds and Sample Collection}

We conducted a pilot mastitis BTSCC-based control program on 19 herds of Murciano-Granadina goats in the Murcia region (southeast Spain). The herds ranged in size from 80 to 170 lactating goats. In all of the herds, weekly BTSCC were performed from October to April. In all cases of clinical mastitis communicated by the farmer, milk samples were processed for bacteriological analysis. Moreover, milk samples from udder halves without visible signs of abnormal milk were processed according to farmer criteria (previous mastitis records, milk losses, chronic mastitis, or atrophic udder half). Bacteriological analyses were also performed on synovial fluid and ocular swabs when CA was suspected. In total, 182 milk samples and 15 synovial fluid samples and ocular swabs were processed over the 7-mo period.

\section{BTSCC}

Bulk tank samples for SCC were added with azidiol, refrigerated for $24 \mathrm{~h}$ after collection, and processed using a Fossomatic 90 instrument (Foss Electric, Hillerød, Denmark) after a heat treatment at $60^{\circ} \mathrm{C}$ for $15 \mathrm{~min}$ (Miller et al., 1986).

\section{Bacteriological Procedures}

All bacteriological procedures were performed according to the recommendations of the National Mastitis Council (NMC) (Harmon et al., 1990). Prior to morning milking, teats were swabbed with $70 \%$ ethanol. After discarding the first 3 streams, $10-\mathrm{mL}$ milk samples were collected into sterile tubes. Samples were kept at $4^{\circ} \mathrm{C}$ and immediately transported to the laboratory for bacteriological analysis. A $0.01-\mathrm{mL}$ aliquot of each sample was plated onto Columbia $5 \%$ sheep blood agar plates (BioMérieux, Marcy l'Etoile, France). Plates were incubated aerobically at $37^{\circ} \mathrm{C}$ and examined at 24, 48, and $72 \mathrm{~h}$.

Mycoplasmas were identified by culturing samples using modified Hayflick medium in duplicate (agar and broth), incubating in a high humidity $\mathrm{CO}_{2}(5 \%)$ incubator for $2 \mathrm{~d}$, passaging on agar media, subpassaging in broth, and incubating for a further $9 \mathrm{~d}$. The biochemical profiles of isolates were established as follows: sensitivity to digitonin, arginine and urea hydrolysis, fermentation of glucose, phosphate activity, film and spot production, tetrazolium reduction, liquefaction of inspissated serum, and digestion of casein and hemoadsorption (Poveda, 1998). Serological identification was performed using monospecific hyperimmune antisera obtained from rabbits against all reference strains of ovine and caprine mycoplasmas using Growth Inhibition Test (Poveda and Nicholas, 1998). The strains were finally identified by PCR (Tola et al., 1996, 1997). The primers amplify a fragment of a $375 \mathrm{bp}$, yielding a rapid, sensitive, and specific detection of Mycoplasma agalactiae.

\section{Calculating the 3-mo Geometric Mean}

Rolling geometric means were calculated from individual weekly averages for the preceding 3 complete months, according to NMC Guidelines for Accurate Sampling and Reporting of Bulk Milk Cell Counts (NMC, 2002).

\section{Statistical Analysis}

The BTSCC logarithm was used to normalize the BTSCC distribution. Statistical analyses were conducted using SPSS 11.0 software (Standard version; SPSS Inc., Chicago, IL). The homogeneity of variance was determined by the Levenne test. Mean BTSCC were compared by ANOVA. The $F$ statistic was used when the variance was homogeneous and by the BrownFoshyte statistic when it was nonhomogeneous. Mean data were compared using posthoc tests.

Our second objective was to determine the implications of BTSCC regulations for Murciano-Granadina goats.

To examine the present situation of the MurcianoGranadina goat herd in view of the imminent BTSCC legal limits for producing goat milk, we collected weekly bulk tank milk samples for SCC from 65 herds from October to May $(n=2693)$. These BTSCC data were obtained using the same method as described for the first objective. A mixed model procedure using SAS 6.11 software (1996) was used to establish the effect of the herd and the lactation month on the BTSCC. Monthly rolling values were calculated for each herd using data collected over the preceding 3 complete months (NMC, 2002). At least one datum was collected each month (EU normative for cow's milk). This system of calculation is used by the milk industry for payment by quality.

Four thresholds were considered: 1) 1,750,000 cells/ $\mathrm{mL}$, the limit proposed by De Crémoux et al. (1996) to 
Table 1. Mycoplasma isolation according to herd and month.

\begin{tabular}{lll}
\hline & \multicolumn{2}{c}{ Mycoplasma isolation } \\
\cline { 2 - 3 } $\begin{array}{l}\text { Herd } \\
\text { number }\end{array}$ & $\begin{array}{l}\text { Positive samples } \\
\text { (no. of milk samples) }\end{array}$ & $\begin{array}{l}\text { Month of } \\
\text { lactation }\end{array}$ \\
\hline 6 & 3 & 1 and 2 \\
9 & 6 & 3,5, and 7 \\
11 & 5 & $6^{1}$ \\
13 & 3 & 3 \\
17 & $2+1$ synovial fluid sample & 5 and 7 \\
\hline
\end{tabular}

${ }^{1}$ Clinical outbreak of contagious agalactia.

identify IMI caused by a major pathogen; 2) 1,500,000 cells/mL, proposed by Barbosa et al. (1994); 3) 1,000,000 cells $/ \mathrm{mL}$, proposed by the French association of goat's milk producers and processors (Charpentier, 2000) and stipulated by the USA Grade A Pasteurized Milk Ordinance; and 4) 750,000 cells/mL, proposed by De Crémoux et al. (1996) to preclude IMI by a minor pathogen. This last limit may be used as an indicator of herd quality. For each 3-mo period, we calculated the percentage of herds that would be penalized according to each limit.

\section{RESULTS AND DISCUSSION}

\section{Objective 1}

Of a total of 182 milk samples analyzed, 19 samples from 5 herds showed mycoplasma isolation (Table 1). Of the 15 samples of synovial fluid or eye swabs, only one was mycoplasma positive (Table 1). A clinical outbreak of classic CA was declared in herd 11 in March. The disease practically affected all lactating goats, leading to a notable drop in milk production and considerably increased cell counts. In herds $6,9,13$, and 17, mycoplasma-infected animals were culled, with no episodes of CA or observed repercussions on milk yield.

All of the mycoplasmas isolated were identified as $M$. agalactiae, known to be responsible for most cases of caprine CA detected in Spain (Real et al., 1994; Gil et al., 1999). When a herd with no history of previous CA becomes infected, the disease manifests as severe episodes of bilateral mastitis, affecting almost all lactating goats (even those with keratoconjunctivitis or arthritis) with low mortality among adult animals. Young goats are severely affected and show septicemia or polyarthritis. Herds with a history of chronic CA infection show sporadic cases of mastitis, normally after kidding, and the offspring may also suffer septicemia or polyarthritis (Bergonier et al., 1997). In 3 of the present herds (6, 9, and 17 with no previous CA) $M$. agalactiae infection developed in an atypical manner, as it did not clinically spread to other lactating goats. Infection by $M$. agalactiae may run a subclinical course, whereby the microorganism probably settles in lymph nodes and is excreted in the milk. This occurs both in herds with chronic agalactia and even in animals infected for the first time when there is no history of mycoplasma infection in the herd (Bergonier et al., 1997; Sanchis et al., 1998; Sanchis et al., 2000), which may have several explanations. One such explanation is the normal dynamics of infection in young animals. When the natural challenge inoculum of mycoplasma is moderate and the goats are well managed, the microorganism settle in lymph nodes, which can give rise to several clinical pictures during situations of immunocompromise, such as during parturition or in early lactation (Sanchis et al., 1998). As a further possible explanation, it has been speculated that there could be less aggressive mycoplasma strains that give rise to mammary excretion without symptomatology (Bergonier et al., 1997). In the present study, CA onset of low clinical intensity might have something to do with the endemic presence of the disease in the region, along with the good management practices and measures implemented in the herds. These essentially include the immediate culling of diseased animals and hygienic milking practices in which teats are disinfected in hypochlorite solution (1400 ppm chlorine). Resistance toward mycoplasma infection in endemic areas is consistent with the conclusions reported by Bergonier et al. (1996), who observed that sheep experimentally infected with $M$. agalactiae were resistant to further infection.

The mean log BTSCC for the 7-mo study period was $5.89 \pm 0.28$ in herds in which no mycoplasmas were isolated, $5.91 \pm 0.31$ in mycoplasma-infected herds without clinical CA, and $6.47 \pm 0.32$ in the herd with CA (Table 2). The posthoc tests revealed that only the herd

Table 2. Means of bulk tank milk SCC (BTSCC) according to mycoplasma isolation and the contagious agalactia (CA) clinical status of the herds.

\begin{tabular}{lllc}
\hline $\begin{array}{l}\text { Mycoplasma isolation status } \\
\text { (no. of herds) }\end{array}$ & $\begin{array}{l}\text { Samples } \\
\text { (no.) }\end{array}$ & $\begin{array}{l}\text { Mean log } \\
\text { BTSCC }\end{array}$ & $\begin{array}{l}\text { Geometric mean } \\
\text { (cells/mL) }\end{array}$ \\
\hline No mycoplasma isolation (14) & 1053 & $5.89^{\mathrm{a}} \pm 0.2$ & $776 \times 10^{3}$ \\
Mycoplasma isolation; no clinical CA (4) & 579 & $5.91^{\mathrm{a}} \pm 0.31$ & $813 \times 10^{3}$ \\
Clinical CA (1) & 27 & $6.47^{\mathrm{b}} \pm 0.32$ & $2951 \times 10^{3}$ \\
\hline
\end{tabular}

${ }^{\mathrm{a}, \mathrm{b}}$ Means with different superscripts differ significantly $(P<0.01)$. 
Table 3. Three-month rolling means of log bulk tank SCC (geometric means, cells $/ \mathrm{mL}$ ) according to mycoplasma isolation and the contagious agalactia (CA) clinical status of the herds.

\begin{tabular}{llcr}
\hline & $\begin{array}{l}\text { No mycoplasma } \\
\text { infection }\end{array}$ & $\begin{array}{l}\text { Mycoplasma infection } \\
\text { (no clinical CA) }\end{array}$ & CA \\
\hline First, second, third & $5.98 \pm 0.23^{\mathrm{a}}$ & $6.04 \pm 0.16^{\mathrm{b}}$ & $6.32 \pm 0.12^{\mathrm{c}}$ \\
& $\left(955 \times 10^{3}\right)$ & $\left(1096 \times 10^{3}\right)$ & $\left(2089 \times 10^{3}\right)$ \\
Second, third, fourth & $5.97 \pm 0.22^{\mathrm{a}}$ & $6.03 \pm 0.16^{\mathrm{b}}$ & $6.26 \pm 0.14^{\mathrm{c}}$ \\
& $\left(933 \times 10^{3}\right)$ & $\left(1071 \times 10^{3}\right)$ & $\left(1819 \times 10^{3}\right)$ \\
Third, fourth, fifth & $5.96 \pm 0.25 \pm 0.14^{\mathrm{b}}$ \\
& $\left(912 \times 10^{3}\right)$ & $5.99 \pm 0.21^{\mathrm{a}}$ & $\left(1778 \times 10^{3}\right)$ \\
Fourth, fifth, sixth & $5.90 \pm 0.23^{\mathrm{a}}$ & $\left(977 \times 10^{3}\right)$ & $6.40 \pm 0.29^{\mathrm{b}}$ \\
Fifth, sixth, seventh & $\left(794 \times 10^{3}\right)$ & $5.86 \pm 0.33^{\mathrm{a}}$ & $\left(2511 \times 10^{3}\right)$ \\
& $5.79 \pm 0.31^{\mathrm{a}}$ & $\left(724 \times 10^{3}\right)$ & $6.68 \pm 0.33^{\mathrm{b}}$ \\
& $\left(616 \times 10^{3}\right)$ & $5.74 \pm 0.38^{\mathrm{a}}$ & $\left(4786 \times 10^{3}\right)$ \\
\hline
\end{tabular}

${ }^{a, b}$ Means in rows showing different superscripts differ significantly $(P<0.01)$.

that suffered a clinical CA outbreak showed counts that were significantly higher $(P<0.01)$. No significant differences were found between herds not showing clinical episodes of CA, regardless of whether the mycoplasma had been isolated or not (Table 2). When differences are analyzed month by month, counts for the herd with clinical CA symptoms were always significantly higher than those for herds with no mycoplasma infection or for counts recorded for infected herds that failed to show clinical episodes of CA, with the exception of the month of December. Among the herds showing no clinical CA episodes, only the presence of intramammary mycoplasma infection led to differences in the BTSCC for the months of November and December. These findings suggest that, in the absence of an outbreak of clinical $\mathrm{CA}$, certain intramammary mycoplasma infections fail to affect the BTSCC. Hence, it is difficult to suspect a mycoplasma infection based on the BTSCC. This may be a consequence that infected animals do not always undergo large BTSCC increases and that any increase occurs when mycoplasma are recovered from milk (Bergonier et al., 1996). Moreover, if a low number of the animals excrete the mycoplasma and if some of the infected milk does not reach the tank (in cases of clinical mastitis), then the impact on the bulk tank SCC will be minimal. In addition, high cell counts can be attributable to noninfectious factors (Paape et al., 2001, McDougall and Voermans, 2002), such that a high BTSCC is only indicative of a risk of mycoplasm infection, requiring subsequent laboratory confirmation. Given the importance of CA in the Mediterranean area, control programs for mastitis need to include a surveillance system to monitor mycoplasma infections based on periodic, specific microbiological tests. Indeed, the tank cell count will only alert us of a problem when it is too late to be efficiently resolved.

From a standpoint of future restrictions for milk production and the pay-by-quality system adopted by some milk industries, it would be better to calculate counts as rolling geometric 3-mo means (Table 3). Despite the recognized prevalence and spread of CA in the Mediterranean basin, the impact of mycoplasma infection on the BTSCC has been hardly addressed. The situation is even more striking if we take into account that European Community Directive 92/46 (Directive 92/46ECC Council, 1992) is the doorway to a potential future restriction for marketing the milk of small ruminants, depending on the BTSCC, although the threshold proposed so far of $1,500,000$ cell $\mathrm{s} / \mathrm{mL}$ is fairly high (Barbosa et al., 1994). In the present study, although the first two 3-mo geometric means were significantly higher in mycoplasma-infected herds without clinical CA than in noninfected herds, they were still well below this 1,500,000-cells $/ \mathrm{mL}$ limit. The herd with CA consistently showed very high counts, always exceeding 1,500,000 cell $\mathrm{s} / \mathrm{mL}$, with a considerable increase in the month the outbreak was declared (Table 3). However, because of the type of follow up this herd was subjected to, we lack data on the possible milk excretion of the mycoplasma prior to the clinical outbreak. It may be assumed that these animals had IMI caused by mycoplasma since the start of the lactation period, although the clinical outbreak was not declared until March.

\section{Objective 2}

The mixed model used revealed a significant effect of herd and month $(P<0.001)$ on the BTSCC. In Southeast Spain, there is a tendency to synchronize the herd for kidding in September and October; thus, the effect of stage of lactation can be substantial. The use of rolling geometric measures is designed to reduce the effects of isolated high values (NMC, 2002) and detect masked tendencies (Thrusfield, 1995). Despite this, the management practice described previously determines that noncompliance mostly occurs when using rolling means that include the initial and final months of lactation (Table 4). The introduction of a payment-by-quality system based on the BTSCC would probably induce a change in parturition management, such that there will 
Table 4. Percentage of Murciano-Granadina goat herds not complying with the thresholds applied during lactation according to their 3 -mo rolling geometric means.

\begin{tabular}{llllll}
\hline & \multirow{2}{*}{$\begin{array}{l}\text { Geometric } \\
\text { means }\end{array}$} & \multicolumn{3}{c}{ BTSCC $^{1}$ threshold (cells/mL) } \\
\cline { 3 - 5 } & & 750,000 & $1,000,000$ & $1,500,000$ & $1,750,000$ \\
\cline { 3 - 5 } & & & & & \\
\cline { 3 - 5 } & & & & & \\
First, second, third & $1000 \times 10^{3}$ & 80 & 64.5 & 8.9 & 4.4 \\
Second, third, fourth & $920 \times 10^{3}$ & 75 & 46.2 & 7.7 & 1.9 \\
Third, fourth, fifth & $874 \times 10^{3}$ & 74 & 40 & 4 & 2 \\
Fourth, fifth, sixth & $755 \times 10^{3}$ & 59 & 19.7 & 3.3 & 1.6 \\
Fifth, sixth, seventh & $685 \times 10^{3}$ & 63.5 & 30.2 & 3.2 & 3.2 \\
Sixth, seventh, eighth & $683 \times 10^{3}$ & 72.5 & 37.5 & 10 & 5 \\
Total & $820 \times 10^{3}$ & 69.8 & 38.3 & 7.1 & 3.2 \\
\hline
\end{tabular}

${ }^{1}$ BTSCC = bulk tank SCC.

always be a proportion of animals in the middle of lactation on the farm, to counter balance the increased physiological demands of animals at the start or end of the lactation period (Rota et al., 1993; Wilson et al., 1995; Zeng et al., 1997). Such a system of several yearly kiddings also benefits the industry, because it avoids the current seasonal variation in production that gives rise to a shortage of milk during the summer months.

Table 4 shows the proportions of herds that would be penalized according to the different limits considered. The 1,750,000-cells/mL limit proposed to identify major pathogen infection at the udder level is of little use at the tank level. In goat subclinical mastitis, the most prevalent pathogens are coagulase-negative staphylococci (Bergonier et al., 2003; Contreras et al., 2003). As a consequence, the $1,750,000-$ cells $/ \mathrm{mL}$ threshold would only be surpassed by a few herds with serious problems, such as the present herd showing clinical signs of CA (Table 3), or by herds with a low milk yield (Baudry et al., 1993). The 1,500,000 cells/mL proposed by Barbosa et al. (1994) to the EU authorities also seems to be a highly conservative limit. Despite the higher cell content of goat's milk (Paape and Contreras, 1997) in comparison with the SCC of cow's milk and the lack of mastitis control measures in most of the herds in our setting, it may be noted that the proportion of herds not complying would be extremely low. Charpentier (2000) proposes that this limit be adopted in a preliminary stage, and the 1,000,000-cells/mL limit enforced when $70 \%$ of herds yield an SCC $<1,500,000$ cells $/ \mathrm{mL}$. Although, in our area, $70 \%$ of herds show a SCC $<1,500,000$ cells $/ \mathrm{mL}$ (Table 4), we feel the introduction of the legal limit should be temporarily delayed, such that farmers understand the need to adopt mastitis control programs aimed at lowering the BTSCC. We may also assume that the payment-by-quality policy will increase the number of herds maintaining counts under this level. Herein, only $30 \%$ of the herds showed bulk tank counts $<750,000$ cells $/ \mathrm{mL}$ at any given time during the lactation period (Table 4 ). In dairy goats, the minor pathogens, mainly coagulase-negative staphylococci, make up the most etiologically significant group causing mastitis, which is highly prevalent in herds not subjected to basic control measures such as postmilking teat dipping or antibiotic drying treatments (Contreras et al., 2003). De Crémoux et al. (1996) suggested the use of this threshold to discriminate IMI caused by minor pathogens at the level of the udder. This appears to indicate that herds subjected to a mastitis prevention program and showing a low incidence of mastitis would score below this threshold. It is these herds that will also produce the highest amounts of high quality milk (Baudry et al., 1993). Charpentier (2000) suggested abandoning the payment-by-quality system when $70 \%$ of herds show counts $<1,000,000$ cells $/ \mathrm{mL}$, although we feel there should be some economic incentive for farmers who make an effort to maintain their herds at $<750,000$ cells $/ \mathrm{mL}$.

Although other published reports on goat milk BTSCC calculate overall geometric means by months or entire lactation instead of 3-mo rolling geometric means, these data serve to evaluate the situation in other countries.

In the US, where the legal limit is $1,000,000$ cells/ $\mathrm{mL}$, Haenlein (1996) highlights the problem of seasonal kidding. Hence, $>40 \%$ of the bulk tank counts for August to January would exceed this legal limit, because, during this period, many herds are at the final stages of lactation. However, during the rest of the year, the percentage of infractions would be of the order 10 to $30 \%$. In contrast, Paape et al. (2001) indicated that only $8.3 \%$ of herds would comply with the 750,000 -cells $/ \mathrm{mL}$ limit and $34.5 \%$ with the $1,000,000$-cells $/ \mathrm{mL}$ limit; therefore, those researchers recommended that the legal limit should not be $<1,500,000$ cells $/ \mathrm{mL}$. This opinion is shared by Barbosa et al. (1994) for the EU and would avoid the current bias for the goat milk industry and would also harmonize EU and US legislation.

In France, $25.9 \%$ of goat herds would show BTSCC means $<1,000,000$ cells $/ \mathrm{mL}$, and $75.8 \%$ would show 
BTSCC means $<1,500,000$ cells/mL (De Crémoux, 2000). However, the proportion of herds not complying would be lower, because, during the first 6 mo of the year, which is when most caprine milk is produced in France, milk SCC are ostensibly lower. This would imply a decrease in the 3-mo rolling geometric means. Further, if there were to be a change in management toward continued production throughout the year, lower stable counts would be obtained. The situation in Italy seems to be more problematic, with yearly geometric BTSCC means generally in excess of 1,500,000 cells/mL (Cuccuru, 2000). It is clear that we need to consider that the regulations finally adopted will apply to Europe; thus, the limits for marketing goat milk should protect the interests of all EU producers. Future legislation should attempt to be compatible with national regulations that may impose lower limits, depending on the real situation of the country concerned.

\section{CONCLUSIONS}

When there is no evidence of clinical CA in goats herds, the presence of a few mycoplasma-infected animals does not give rise to increased BTSCC, provided that the farm follows basic measures of hygiene and that infected animals are rapidly removed from the herd. Given that CA is widespread in the Mediterranean basin, the disease needs to be closely monitored by implementing active control measures. Surveillance based solely on the BTSCC will only identify herds with problems beyond easy solutions, although persistently high counts should be considered a risk factor. The limit most likely to be imposed in the EU (1,500,000 cells/ $\mathrm{mL}$ ) is highly conservative in terms of the available data for Spain and France, but it should not be forgotten that, across the EU, goat breeds differ, as do their production systems and final BTSCC. For some of these breeds and systems, lowering this threshold would lead to economic disaster. We feel that any new SCC legislation will need to be accompanied by economic benefits for farmers whose herds show low BTSCC. This would prompt the necessary efforts to lower the BTSCC to control mastitis and to adopt management systems designed to avoid the stage of lactation effect on the BTSCC.

\section{ACKNOWLEDGMENTS}

This study was funded by the INIA (CAL00-046-C301). The authors thank Carlos Fernández (Facultad de Veterinaria, Universidad Cardenal Herrera-CEU) for help with the statistical analysis.

\section{REFERENCES}

Adkinson, R. W., R. H. Gough, R. Graham, and A. Yilmaz. 2001. Implications of proposed changes in bulk tank somatic cell count regulations. J. Dairy Sci. 84:370-374.

Barbosa, M., F. Barillet, X. Berthelot, S. Casu, A. Foglini, D. Gabiña, G. Jaubert, G. Kalantzopoulos, A. Ledda, G. Perrin, B. Poutrel, J. Renaud, and R. Rubino. 1994. Conclusioni del comitato Scientifico. International Symposium: "Somatic cells and milk of small ruminants." Bella (Italia).

Baudry, C., G. Jaubert, and G. Perrin. 1993. Typology of goat flocks based on somatic-cell counts in bulk milk. Rev. Méd. Vét. 144:335-341.

Bergonier, D., G. Gracianette, C. Andrieu, X. Berthelot, M. C. Blanc, M. F. Blanc, I. Pujol, and S. Cegouffin. 1996. Experimental contagious agalactiae in ewes-Individual cell counts for 3 consecutive lactations. Pages 93-97 in Somatic Cells and Milk of Small Ruminants. R. Rubino, ed. Pudoc, Wageningen, The Netherlands.

Bergonier, D., X. Berthelot, and F. Poumarat. 1997. Contagious agalactia of small ruminants: Current knowledge concerning epidemiology, diagnosis and control. Rev.-Off. Int. Epizoot. 16:848-873.

Bergonier, D., R. De Crémoux, R. Rupp, G. Lagriffoul, and X. Berthelot. 2003. Mastitis of dairy small ruminants. Vet. Res. 34:689-716.

Charpentier, P. 2000. Paiement du lait de chèvre à la qualité: preconisations de l'interprofession. Pages 761-763 in 7th Int. Conf. Goats, France. L. Gruner and Y. Chabert, eds. Institut de L'Elévage and INRA. Ivry-Sur-Seine, France.

Contreras, A., C. Luengo, A. Sanchez, and J. C. Corrales. 2003. The role of intramammary pathogens in dairy goats. Livest. Prod. Sci. $79(2-3): 273-283$

Cuccuru, C. 2000. Recuentos de células somáticas en leche de cabra: Situación y estrategias de control en Italia. Ovis 67:41-53.

De Crémoux, R. 2000. Células somáticas en leche de cabra y estrategias de control. situación en Francia. Ovis 67:35-40.

De Crémoux, R., B. Poutrel, R. Pillet, G. Perrin, M. Ducellier, and V. Heuchel. 1996. Cell counts for diagnosing caprine bacterial mammary infections. Pages 35-39 in Somatic Cells and Milk of Small Ruminants. R. Rubino, ed. Pudoc, Wageningen, The Netherlands.

Directive 92/46ECC Council. 1992. Directive 92/46ECC Council. Diario oficial de las Comunidades Europeas. L 268:1-34. European Council. Brussels, Belgium.

Gil, M. C., M. Hermoso de Mendoza, J. Rey, J. M. Alonso, J. B. Poveda, and J. Hermoso de Mendoza. 1999. Aetiology of caprine contagious agalactia syndrome in Extremadura, Spain. Vet. Rec. 144:24-25.

Haenlein, G. F. W. 2002. Relationship of somatic cell counts in goat milk to mastitis and productivity. Small Rumin. Res. 45:163-178.

Haenlein, G. F. W. 1996. Status and prospects of the dairy goat industry in the United States. J. Anim. Sci. 74:1173-1181.

Harmon, R. J., R. J. Eberhart, D. E. Jasper, B. E. Langlois, and R. A. Wilson. 1990. Microbiological Procedures for the Diagnosis of Bovine Udder Infection. 3rd ed. National Mastitis Council, Inc., Arlington, VA.

McDougall, S., and M. Voermans. 2002. Influence of estrus on somatic cell count in dairy goats. J. Dairy Sci. 85:378-383.

Miller, R. H., M. J. Paape, and J. C. Acton. 1986. Comparison of milk somatic cell counts by Coulter and Fossomatic counters. J. Dairy Sci. 69:1942-1946.

National Mastitis Council, Inc. 2002. Ch. 5 in NMC Guidelines For Accurate Sampling and Reporting of Bulk Milk Cell Counts. Available: http://www.nmconline.org/docs/BTSCCguide.pdf. Accessed Nov. 3, 2003.

Paape, M. J., and A. Contreras. 1997. Historical perspective on the evolution of the milk somatic cell count. Flemish Vet. J. Suppl. 66:1-13.

Paape, M. J., B. Poutrel, A. Contreras, J. C. Marco, and A. V. Capuco. 2001. Milk somatic cells and lactation in small ruminants. J. Dairy Sci. 84(Suppl E):E237-E244.

Poutrel, B., R. De Crémoux, R. Pillet, V. Heuchel, and M. Duceilliez. 1996. Relations entre statut infectieux des mamelles et numera- 
tions cellulaires du lait de chèvre. Pages 61-64 in Somatic Cells and Milk of Small Ruminants. R. Rubino, ed. Pudoc, Wageningen, The Netherlands.

Poveda, J. B. 1998. Biochemical characteristics in Mycoplasma identification. In Methods in Molecular Biology: Mycoplasma Protocols. 1st ed. R. J. Miles, and R. A. Nicholas, ed. Humana Press Inc., Totowa, NJ.

Poveda, J. B., and R. A. J. Nicholas. 1998. Serological identification of mycoplasmas by growth and metabolism inhibition test. In Methods in Molecular Biology: Mycoplasma Protocols. 1st ed. R. J. Miles and R. A. J. Nicholas, ed. Humana Press Inc., Totowa, NJ.

Real, F., S. Deniz, B. Acosta, O. Ferrer, and J. B. Poveda. 1994. Caprine contagious agalactia caused by Mycoplasma agalactiae in the Canary Islands. Vet. Rec. 135:15-16.

Rota, A. M., C. Gonzalo, P. L. Rodriguez, A. I. Rojas, L. Martin, and J. J. Tovar. 1993. Effects of stage of lactation and parity on somatic cell counts in milk of Verata goats and algebraic models of their lactation curves. Small Rumin. Res. 12:211-219.

Sanchis, R., G. Abadie, M. Lambert, E. Cabasse, P. Dufour, J. M. Guibert, and M. Pépin. 2000. Inoculation of lactating ewes by the intramammary route with Mycoplasma agalactiae: Comparative pathogenicity of six field strains. Vet. Res. 31:329-337.
Sanchis, R., G. Abadie, M. Lambert, E. Cabasse, J. M. Guibert, M. Calamel, P. Dufour, C. Vitu, M. Vignoni, and M. Pépin. 1998. Experimental conjunctival-route infection with Mycoplasma agalactiae in lambs. Small Rumin. Res. 27:31-39.

SAS/STAT Software. 1996. Changes and Enhancements Through Release 6.11. SAS Inst., Inc., Cary, NC.

Tola, S., G. Idini, D. Manunta, G. Galleri, P. P. Angioi, A. M. Rocchigiani, and G. Leori. 1996. Rapid and specific detection of Mycoplasma agalactiae by polymerase chain reaction. Vet. Microbiol. 51:77-84.

Tola, S., P. P. Angioi, A. M. Rocchigiani, G. Idini, D. Manunta, G. Galleri, and G. Leori. 1997. Detection of Mycoplasma agalactiae in sheep milk samples by polymerase chain reaction. Vet. Microbiol. 54:17-22.

Thrusfield, M. 1995. Veterinary Epidemiology. 2nd ed. Blackwell Science Ltd., Oxford, England.

Wilson, D. J., K. N. Stewart, and P. M. Sears. 1995. Effects of stage of lactation, production, parity and season on somatic cell counts in infected and uninfected dairy goats. Small Rumin. Res. 16:165-169.

Zeng, S. S., E. N. Escobar, and T. Popham. 1997. Daily variations in somatic cell count, composition, and production of Alpine goat milk. Small Rumin. Res. 26:251-258. 